\title{
FAKTOR-FAKTOR YANG BERHUBUNGAN DENGAN PERILAKU WUS (WANITA USIA SUBUR) TENTANG DETEKSI DINI KANKER LEHER RAHIM METODE IVA (INSPEKSI VISUAL ASAM ASETAT) DI PUSKESMAS SINGGANI
}

\author{
${ }^{1}$ Niar Rasyid, ${ }^{2}$ Nur Afni \\ ${ }^{1}$ Bagian Biostatistik, Fakultas Kesehatan Masyarakat, Universitas \\ Muhammadiyah Palu \\ ${ }^{2}$ Bagian Administrasi Kebijakan Kesehatan, Fakultas Kesehatan \\ Masyarakat, Universitas Muhammadiyah Palu
}

\begin{abstract}
ABSTRAK
Berdasarkan data Dinas Kesehatan Provinsi Sulawesi Tengah kasus kanker leher rahim yang terjadi sebanyak 140 kasus pada tahun 2015. Hasil data Puskesmas Singgani tahun 2015 pemeriksaan IVA yang dilakukan sebanyak 780 orang wanita usia subur (WUS) diantara umur 3050 tahun dari jumlah keseluruhan WUS sebanyak 1330 orang. Tujuan penelitian ini adalah untuk mengetahui faktor-faktor yang berhubungan dengan perilaku WUS tentang deteksi dini kanker leher rahim metode IVA di Puskesmas Singgani. Desain penelitian ini adalah penelitian survei analitik dengan pendekatan cross sectional. Populasi dalam penelitian ini adalah wanita usia subur yang melakukan pemeriksaan di Puskesmas Singgani. Analisis yang digunakan dalam penelitian ini adalah analisis uji chi-square. Hasil penelitian ini menunjukkan bahwa tidak ada hubungan antara pengetahuan dengan perilaku WUS dengan nilai $p=0,443>0,05$, tidak ada hubungan antara pendidikan dengan perilaku WUS dengan nilai $p$ $=0,488>0,05$, tidak ada hubungan antara umur dengan perilaku WUS dengan nilai $p=0,265>0,05$, tidak ada hubungan antara pekerjaan dengan perilaku WUS dengan nilai $p=0,393>0,05$, tidak ada hubungan antara dukungan suami/keluarga dengan perilaku WUS dengan nilai $p=$ $0,063>0,05$, ada hubungan antara dukungan petugas kesehatan dengan perilaku WUS dengan nilai $p=0,002<0,05$. Petugas kesehatan diharapkan memberikan informsasi tentang kanker leher rahim beserta pencegahannya. Agar masyarakat mengetahui dampak dan risiko tidak melakukan deteksi dini kanker leher rahim metode IVA.
\end{abstract}

Kata Kunci: Perilaku, kanker leher rahim, metode IVA 


\section{PENDAHULUAN}

Kanker

adalah

pertumbuhan abnormal dari suatu

sel atau jaringan dimana sel atau jaringan tersebut tumbuh dan berkembang tidak terkendali, kecepatan tumbuhnya berlebihan, dan akhirnya mengganggu organ lain. Kanker serviks adalah kanker yang berasal dan tumbuh pada serviks, khususnya epitel atau lapisan luar permukaan serviks dan disebabkan oleh infeksi virus Human Papilloma Virus (HPV)(Samadi, 2011).

WHO (World Health

Organization) menyatakan terdapat lebih dari 92 ribu kasus kematian pada penduduk wanita akibat penyakit kanker. Sebesar 10,3 persennya merupakan jumlah kematian akibat kanker leher rahim. Sedangkan jumlah kasus baru kanker serviks berjumlah hampir 21 ribu.Di Indonesia kanker leher rahim menduduki urutan kedua dari 10 kanker terbanyak berdasar data dari Patologi Anatomi tahun 2010 dengan insidens sebesar $12,7 \%$. Menurut perkiraan Kementerian Kesehatan RI saat ini, jumlah wanita penderita baru kanker serviks berkisar 90-100 kasus per 100.000 penduduk dan setiap tahun terjadi 40 ribu kasus kanker leher rahim (Kemenkes RI, 2015).

Berdasarkan data Dinas Kesehatan Provinsi Sulawesi
Tengah kasus kanker leher rahim yang terjadi sebanyak 140 kasus pada tahun 2015. Peningkatan kasus baru kanker serviks karena gerakan deteksi dini kanker serviks melalui Inspeksi Visual Asam Asetat (IVA) telah dilaksanakan oleh seluruh kabupaten/kota se-provinsi Sulawesi Tengah. Hingga tahun 2015, dari 459.403 WUS telah dilaksanakan pemeriksaan IVA kepada 10.831 WUS. (Profil Dinkes Sulteng, 2015)

Sedangkan berdasarkan data Puskesmas Singgani tahun 2015 pemeriksaan IVA yang dilakukan sebanyak 780 orang wanita usia subur (WUS) diantara umur 30-50 tahun dari jumlah keseluruhan WUS sebanyak 1330 orang. (Profil Puskesmas Singgani, 2015).

Ada beberapa faktor yang mendukung WUS (Wanita Usia Subur) melakukan pemeriksaan IVA (Inspeksi Visual dengan pulasan Asam asetat) yaitu: faktor pendidikan, faktor pengetahuan, dan dukungan keluarga. Masalah lain dalam usaha skrining kanker serviks ialah keengganan wanita diperiksa karena malu. Penyebab lain ialah kerepotan, keraguan akan pentingnya pemeriksaan, kurangnya pengetahuan tentang 
pentingnya pemeriksaan, takut terhadap kenyataan hasil pemeriksaan yang akan dihadapi, ketakutan merasa sakit pada pemeriksaan, rasa segan diperiksa oleh dokter pria atau pun bidan dan kurangnya dorongan keluarga terutama suami. (Rina dan Fitria, 2012).

Berdasarkan uraian di atas maka penulis tertarik untuk melakukan penelitian tentang faktor-faktor yang berhubungan dengan perilaku WUS (wanita usia subur) tentang deteksi dini kanker leher rahim metode inspeksi IVA (inspeksi visual asam asetat) di puskesmas singgani.

\section{METODE}

Penelitian ini merupakan penelitian survei analitik dengan pendekatan cross sectional yang dimana rancangan penelitian yang pengukuran dan pengamatannya dilakukan secara bersamaan dalam suatu waktu tertentu. Penelitian ini dilaksanakan di Puskesmas Singgani pada bulan Maret - April 2017. Populasi dalam penelitian ini adalah wanita usia subur yang melakukan pemeriksaan IVA di Puskesmas Singgani. Jumlah sampel yang diteliti sebanyak 94 responden. Analisis data yang digunakan dalam penelitian ini adalah uji chi-square.

\section{HASIL}

Tabel 1

Distribusi Frekuensi Responden Berdasarkan Karakteristik

\begin{tabular}{lcc}
\hline \multicolumn{1}{c}{ Variabel } & Jumlah & $\%$ \\
\hline Umur & & \\
$<20$ dan > 30 (berisiko) & 28 & 29,8 \\
20 dan 30 (tidak berisiko) & 66 & 70,2 \\
Pendidikan & & \\
Rendah (tamat SD/SMP) & 10 & 10,6 \\
Tinggi (tamat SMA/PT) & 84 & 89,4 \\
Pekerjaan & & \\
Tidak bekerja & 54 & 57,4 \\
Bekerja & 40 & 42,6 \\
Status Pernikahan & & 0 \\
Belum Menikah & 0 & 100 \\
Menikah & 94 &
\end{tabular}

Sumber: Data Primer, 2017 
Berdasarkan tabel 1 karateristik responden meliputi 1) umur $<20$ tahun dan $>35$ tahun sebanyak 28 responden $(29,8 \%)$, kelompok umur 25-35 tahun sebanyak 66 responden $(70,2 \%)$, 2) pendidikan dengan tamat SD/SMP sebanyak 10 responden
$(10,6 \%)$, tamat SMA/PT sebanyak 84 responden $(89,4 \%)$, 3) tidak bekerja sebanyak 54 responden $(57,4 \%)$, dan responden yang bekerja sebanyak 40 responden $(42,6 \%)$. 4) status pernikahan sebanyak 94 responden (100\%).

Tabel 2

Hubungan Perilaku WUS tentang Deteksi Dini Kanker Leher Rahim Metode IVA di Puskesmas Singgani

\begin{tabular}{|c|c|c|c|c|c|c|}
\hline \multirow{3}{*}{ Variabel } & \multicolumn{3}{|c|}{ Perilaku } & \multirow{2}{*}{\multicolumn{2}{|c|}{ Jumlah }} & \multirow{3}{*}{$P$ Value } \\
\hline & \multicolumn{2}{|c|}{ Kurang baik } & Baik & & & \\
\hline & $\mathbf{n}$ & $\%$ & n \% & $\mathbf{n}$ & $\%$ & \\
\hline \multicolumn{7}{|l|}{ Pengetahuan } \\
\hline Rendah & 16 & 42,2 & 2257,9 & 38 & 100 & \multirow{2}{*}{0,443} \\
\hline Tinggi & 18 & 32,1 & 3867,9 & 56 & 100 & \\
\hline \multicolumn{7}{|l|}{ Pendidikan } \\
\hline Rendah (SD/SMP) & 5 & 50,0 & 550,0 & 10 & 100 & \multirow{2}{*}{0,488} \\
\hline Tinggi (SMA/PT) & 29 & 34,5 & 5565,5 & 84 & 100 & \\
\hline \multicolumn{7}{|l|}{ Umur } \\
\hline $\begin{array}{l}<20 \text { tahun dan }>30 \text { tahun } \\
\text { (berisiko) }\end{array}$ & 13 & 46,4 & 1553,6 & 28 & 100 & \multirow{2}{*}{0,265} \\
\hline $\begin{array}{l}20 \text { tahun dan }>30 \text { tahun (tidak } \\
\text { berisiko) }\end{array}$ & 21 & 31,8 & 4568,2 & 66 & 100 & \\
\hline \multicolumn{7}{|l|}{ Pekerjaan } \\
\hline Tidak bekerja & 22 & 40,7 & 3259,3 & 54 & 100 & \multirow{2}{*}{0,393} \\
\hline Bekerja & 12 & 30,0 & 2870,0 & 40 & 100 & \\
\hline \multicolumn{7}{|l|}{ Dukungan Suami/Keluarga } \\
\hline Tidak mendukung & 20 & 47,6 & 2252,4 & 42 & 100 & \multirow{2}{*}{0,063} \\
\hline Mendukung & 14 & 26,9 & 3873,1 & 52 & 100 & \\
\hline \multicolumn{7}{|l|}{ Dukungan Petugas Kesehatan } \\
\hline Tidak mendukung & 16 & 64,0 & 936,0 & 25 & 100 & \multirow{2}{*}{0,002} \\
\hline Mendukung & 18 & 26,1 & 5173,9 & 69 & 100 & \\
\hline
\end{tabular}


Hubungan

Pengetahuan dengan Perilaku WUS tentang Deteksi Dini Kanker Leher Rahim Metode IVA di Puskesmas Singgani

Pada tabel 2. Menunjukkan bahwa ada 38 responden yang memiliki pengetahuan rendah, sebanyak 16 orang $(42,2 \%)$ yang memiliki perilaku kurang baik dan sebanyak 22 orang $(57,9 \%)$ yang memiliki perilaku baik. Sedangkan dari 56 responden yang memiliki pengetahuan tinggi, sebanyak 18 orang $(32,1 \%)$ yang memiliki perilaku kurang baik dan sebanyak 38 orang $(67,9 \%)$ yang memiliki perilaku baik. ( $p=0,443$ $>0.05$ )

Hubungan Pendidikan dengan Perilaku WUS tentang Deteksi Dini Kanker Leher Rahim Metode IVA di Puskesmas Singgani

Tabel 2. menampilkan ada 10 responden yang memiliki pendidikan rendah, sebanyak 5 orang $(50,0 \%)$ yang memiliki perilaku kurang baik dan sebanyak 5 orang $(50,0 \%)$ yang memiliki perilaku baik. Sedangkan dari 84 responden yang memiliki pendidikan yang tinggi, sebanyak 29 orang (34,5\%) yang memiliki perilaku kurang baik dan sebanyak 55 orang $(65,5 \%)$ yang memiliki perilaku baik dengan nilai $p=0,488>0,05$.

\section{Hubungan Umur dengan Perilaku WUS tentang Deteksi Dini Kanker Leher Rahim Metode IVA di Puskesmas Singgani}

Nampak pada tabel 2 . bahwa ada 28 responden yang memiliki umur diantara $<20$ tahun dan >35 tahun yang berisiko, sebanyak 13 orang $(46,4 \%)$ yang memiliki perilaku kurang baik dan sebanyak 15 orang $(53,6 \%)$ yang memiliki perilaku baik, dari 66 responden yang memiliki umur diantara 20-35 tahun yang tidak berisiko, sebanyak 21 orang $(31,8 \%)$ yang memiliki perilaku kurang baik dan sebanyak 45 orang $(68,2 \%)$ yang memiliki perilaku baik dengan nilai $\mathrm{p}=$ $0,265>0,05$.

Hubungan Pekerjaan dengan Perilaku WUS tentang Deteksi Dini Kanker Leher Rahim Metode IVA di Puskesmas Singgani

Dalam tabel 2 terlihat ada 54 responden yang tidak bekerja, sebanyak 22 orang $(40,7 \%)$ yang memiliki perilaku kurang baik dan sebanyak 32 orang $(59,3 \%)$ yang memiliki perilaku baik. Sedangkan dari 40 responden yang bekerja, 
sebanyak 12 orang $(30,0 \%)$ yang memiliki perilaku kurang baik, dan 28 orang $(70,0 \%)$ yang memiliki perilaku baik. Dengan nilai $\mathrm{p}=$ $0,393>0,05$.

\section{Hubungan \\ Suami/Keluarga \\ Dukungan dengan \\ Perilaku WUS tentang Deteksi Dini Kanker Leher Rahim Metode IVA di Puskesmas Singgani}

Terlihat pada tabel 2 . nampak ada 42 responden berdasarkan dukungan suami/keluarga yang tidak mendukung sebanyak 20 orang $(47,6 \%)$ yang memiliki perilaku kurang baik dan sebanyak 22 orang (52,4\%) yang memiliki perilaku baik. Sedangkan dari 52 responden berdasarkan dukungan suami/keluarga mendukung sebanyak 14 orang $(26,9 \%)$ yang memiliki perilaku kurang baik dan sebanyak 38 orang $(73,1 \%)$ yang memiliki perilaku baik dengan nilai $p=0,063>0,05$.

\section{Hubungan Dukungan Petugas} Kesehatan dengan Perilaku WUS tentang Deteksi Dini Kanker Leher Rahim Metode IVA di Puskesmas Singgani

Tabel 2. menunjukkan bahwa dari 25 responden berdasarkan dukungan petugas kesehatan yang tidak mendukung sebanyak 16 orang $(64,0 \%)$ yang memiliki perilaku kurang baik dan sebanyak 9 orang $(36,0 \%)$ yang memiliki perilaku baik. Sedangkan dari 69 responden berdasarkan dukungan petugas kesehatan sebanyak 18 orang $(26,1 \%)$ yang memiliki perilaku kurang baik dan sebanyak 51 orang $(73,9 \%)$ yang memiliki perilaku baik. ( $p=0,002$ $<0,05$ )

\section{PEMBAHASAN}

\section{Hubungan Pengetahuan dengan Perilaku WUS tentang Deteksi Dini Kanker Leher Rahim Metode IVA}

Hasil penelitian inimenunjukkan bahwa dari 38 responden yang memiliki pengetahuan rendah, sebanyak 16 orang $(42,2 \%)$ yang memiliki perilaku kurang baik dan sebanyak 22 orang $(57,9 \%)$ yang memiliki perilaku baik. Sedangkan dari 56 responden yang memiliki pengetahuan tinggi, sebanyak 18 orang $(32,1 \%)$ yang memiliki perilaku kurang baik dan sebanyak 38 orang $(67,9 \%)$ yang memiliki perilaku baik.

Secara statistik dalam penelitian ini menunjukkan bahwa tidak ada hubungan pengetahuan dengan perilaku WUS tentang deteksi dini kanker leher rahim. 
Tidak adanya hubungan pengetahuan dengan perilaku WUS tentang deteksi dini kanker leher rahim didukung oleh penelitian Yuli K, dkk (2016) tentang pengetahuan, deteksi dini dan vaksinasi HPV sebagai faktor pencegah kanker serviks di Kabupaten Sukoharjo. Hasil penelitian tersebut menunjukkan tidak ada hubungan antara tingkat pengetahuan dengan kejadian kanker serviks di RSUD Sukoharjo $\quad(p=0,671)$. Pengetahuan sebenarnya merupakan dasar untuk bertindak atau berperilaku benar atau salah dalam mencegah atau mengatasi suatu penyakit. Dengan pengetahuan yang baik, seseorang akan mempunyai sikap yang positif terhadap suatu hal dan akan menentukan tindakan yang perlu dilakukan termasuk upaya untuk berperilaku menghindari hal-hal yang merugikan kesehatan.

Berdasarkan uraian diatas, hal ini diduga karena, wanita usia subur yang melakukan pemeriksaan di Puskesmas Singgani mempunyai pengetahuan yang tinggi dan juga berperilaku baik. Karena tingkat kesadaran mereka terhadap deteksi dini kanker leher rahim metode IVA sangat tinggi. Mereka mengetahui pencegahan kanker leher rahim dengan pemeriksaan
IVA melalui petugas kesehatan, selain itu adanya sistem informasi yang berkembang juga yang menyebabkan mereka tahu tentang faktor risiko kanker leher rahim. Dari hasil wawancara yang peneliti lakukan, ibu-ibu yang tidak melakukan pemeriksaan, beralasan mereka masih belum mengetahui tentang deteksi dini kanker leher rahim tersebut. Selain itu, diantara mereka adapula yang tahu tapi masih malas melakukan pemeriksaan IVA, padahal untuk melakukan deteksi dini sekalipun dilakukan secara gratis dan hasil pemeriksaan juga cepat selesai.

\section{Hubungan Antara Pendidikan dengan Perilaku WUS tentang Deteksi Dini Kanker Leher Rahim Metode IVA}

Temuan dari penelitian ini terlihat ada 10 responden yang memiliki pendidikan rendah, sebanyak 5 orang $(50,0 \%)$ yang memiliki perilaku kurang baik dan sebanyak 5 orang $(50,0 \%)$ yang memiliki perilaku baik. Sedangkan dari 84 responden yang memiliki pendidikan yang tinggi, sebanyak 29 orang $(34,5 \%)$ yang memiliki perilaku kurang baik dan sebanyak 55 orang $(65,5 \%)$ yang memiliki perilaku baik.

Hasil uji statistik chi-square diperoleh nilai $\mathrm{p}=0,488$ 
menunjukkan bahwa tidak ada hubungan antara pendidikan dengan perilaku WUS tentang deteksi dini kanker leher rahim.

Temuan penelitian ini sejalan dengan penelitian yang dilakukan oleh Sri Wahyuni (2013) tentang faktor-faktor yang mempengaruhi deteksi dini kanker serviks di kecamatan ngampel kabupaten ngampel jawa tengah.. Hasil penelitian tersebut menunjukkan tidaknya hubungan antara pendidikan dengan perilaku dengan nilai $p=0,392$. Hal ini menunjukkan orang yang berpengetahuan rendah belum tentu perilakunya kurang baik. Bisa saja hal itu terjadi karena faktor lingkungan sekitar yang mempengaruhi perilaku seseorang dalam melakukan deteksi dini kanker leher rahim.

Hal tersebut diasumsi bahwa mereka yang memiliki pengetahuan tinggi masih ada yang belum menyadari pentingnya melakukan pemeriksaan IVA. Bahkan diantara mereka yang diwawancarai oleh peneliti, mereka yang sebagian berpendidikan tinggi hanya tahu tentang kanker leher rahim tapi tidak mengetahui apa saja faktorfaktor yang mempengaruhinya. Sedangkan wanita yang berpendidikan rendah sebagaian besar berperilaku baik karena mereka masih menyadari pentingnya melakukan pemeriksaan demi kesehatan mereka. Responden yang diwawancarai mengetahui deteksi dini kanker leher rahim melalui leaflet yang ada di puskesmas dan mengetahui dari petugas kesehatan.

\section{Hubungan Antara Umur dengan Perilaku WUS tentang Deteksi Dini Kanker Leher Rahim Metode IVA}

Pada penelitian ini memperlihatkan bahwa ada 28 responden yang memiliki umur diantara $<20$ tahun dan $>35$ tahun yang berisiko, sebanyak 13 orang $(46,4 \%)$ yang memiliki perilaku kurang baik dan sebanyak 15 orang $(53,6 \%)$ yang memiliki perilaku baik, dari 66 responden yang memiliki umur diantara 2035 tahun yang tidak berisiko, sebanyak 21 orang $(31,8 \%)$ yang memiliki perilaku kurang baik dan sebanyak 45 orang $(68,2 \%)$ yang memiliki perilaku baik.

Hasil uji statistik diperoleh nilai $p=0,265$ menunjukkan bahwa tidak ada hubungan antara umur dengan perilaku WUS tentang deteksi dini kanker leher rahim.

Hasil penelitian ini sejalan oleh penelitian yang dilakukan $\mathrm{Ni}$ Luh Putu (2017) bahwa tidak ada 
hubungan umur dengan pemeriksaan IVA pada wanita pekerja seksual di Lokalisasi Sunan Kuning, Wilayah Kerja Puskesmas Lebdosari, Kota Semarang.

Olehnya itu, semakin tinggi usia seseorang maka semakin baik tingkat kesadaran mereka dalam melakukan deteksi dini kanker leher rahim. Akan tetapi berdasarkan hasil penelitian yang dilakukan peneliti ternyata umur diantara 20-35 tahun banyak yang berperilaku baik dan tidak berisiko. Hal itu disebabkan karena pada umur tersebut merupakan perkembangan dewasa dan kematangan dalam berpikir dan bekerja. Karena faktor usia dan juga kematangan dalam berpikir yang mempengaruhi WUS mau melakukan deteksi dini kanker leher rahim. Berdasarkan responden yang diwawancarai mereka yang berusia 20 tahun keatas ada belum pernah memeriksakan IVA. Mereka beralasan tidak pernah dengar tentang pemeriksaan tersebut. Selain itu, beberapa responden ada yang masih belum memahami tentang keuntungan memeriksakan IVA tes.

\section{Hubungan Antara Pekerjaan dengan Perilaku WUS tentang Deteksi Dini Kanker Leher Rahim Metode IVA}

\section{Hasil}

penelitian

menunjukkan bahwa ada 54 responden yang tidak bekerja, sebanyak 22 orang $(40,7 \%)$ yang memiliki perilaku kurang baik dan sebanyak 32 orang $(59,3 \%)$ yang memiliki perilaku baik. Sedangkan dari 40 responden yang bekerja, sebanyak 12 orang $(30,0 \%)$ yang memiliki perilaku kurang baik, dan 28 orang $(70,0 \%)$ yang memiliki perilaku baik.

Secara uji statistik didapatkan bahwa tidak ada hubungan antara pekerjaan dengan perilaku WUS tentang deteksi dini kanker leher rahim. Hasil penelitian ini didukung dengan penelitian yang dilakukan oleh Frida Lina (2014) tentang faktor-faktor yang berhubungan dengan perilaku WUS dalam deteksi dini kanker serviks di kelurahan dwikora medan tahun 2014. Dalam penelitiannya menunjukkan bahwa $p=0,142$ berarti tidak ada hubungan yang signifikan antara pekerjaan dengan perilaku WUS dalam deteksi dini kanker serviks.

Wanita yang bekerja kemungkinan besar lebih sering keluar rumah, dan lebih sering berinteraksi dengan orang lain, 
sehingga informasi yang didapatkan lebih banyak dan kemungkinan terpapar informasi tentang kanker serviks. Menurut asumsi peneliti, wanita usia subur yang diteliti rata-rata bekerja sebagai ibu rumah tangga. Dan sebagian besar dari mereka ada yang mengetahui tentang deteksi dini kanker leher rahim dan ada juga yang kurang mengetahuinya. Mereka berasumsi bahwa kanker leher rahim adalah penyakit yang membahayakan dan mematikan. Selain itu, wanita usia subur yang bekerja sebagian hanya mengetahui faktor risiko kanker leher rahim dari media informasi seperti internet. Faktor ekonomi juga yang mempengaruhi dalam hal pemeriksaan IVA. Karena Ibu rumah tangga yang tidak memiliki jaminan kesehatan sehingga tidak bisa memeriksakan secara gratis untuk IVA test. Dibutuhkan dana untuk mereka yang belum memiliki jaminan kesehatan, mereka juga berpikir akan biaya pemeriksaan yang mahal.

\section{Hubungan Antara Dukungan Suami/Keluarga dengan Perilaku WUS tentang Deteksi Dini Kanker Leher Rahim Metode IVA}

Hasil analisis bivariat menunjukkan bahwa ada 42 responden berdasarkan dukungan suami/keluarga yang tidak mendukung sebanyak 20 orang $(47,6 \%)$ yang memiliki perilaku kurang baik dan sebanyak 22 orang $(52,4 \%)$ yang memiliki perilaku baik. Sedangkan dari 52 responden berdasarkan dukungan suami/keluarga mendukung sebanyak 14 orang $(26,9 \%)$ yang memiliki perilaku kurang baik dan sebanyak 38 orang $(73,1 \%)$ yang memiliki perilaku baik.

Hasil uji statistik chisquare diperoleh nilai $p=0,063$ menunjukkan bahwa tidak ada hubungan antara dukungan suami/keluarga dengan perilaku WUS tentang deteksi dini kanker leher rahim.

Hasil penelitian ini didukung dengan penelitian Christin (2016) dalam penelitiannya faktor-faktor yang berhubungan dengan deteksi dini kanker leher rahim di kecamatan gisting kabupaten tanggamus lampung. Dalam hasil penelitiannya dengan menggunakan Chi-square diperoleh hasil $p$ value $1,000<$ 0,05 sehingga Ho ditolak, maka tidak ada hubungan antara dukungan suami dengan kesediaan WUS dalam melakukan deteksi dini kankerserviks di Puskesmas Manahan Kota Surakarta.

$\mathrm{Hal}$ tersebut diduga karena, dukungan yang diberikan kepada WUS dari suami/keluarga 
bisa berupa pemberian informasi tentang pemeriksaan IVA untuk deteksi dini kanker leher rahim. Dukungan yang diberikan juga berupa respon atau tanggapan yang positif jika responden mengajak diskusi tentang masalah kesehatan wanita, salah satunya kanker serviks dan IVA test. Dan melakukan penyuluhan kepada suami agar menambah pengetahuan tentang kanker serviks dan pemeriksaan IVA, sehingga suami dengan mudah mendorong istrinya untuk melakukan pemeriksaan dini terhadap kanker leher rahim.

\section{Hubungan Antara Dukungan Petugas Kesehatan dengan Perilaku WUS tentang Deteksi Dini Kanker Leher Rahim Metode IVA}

Penelitian ini menunjukkan bahwa ada 25 responden berdasarkan dukungan petugas kesehatan yang tidak mendukung sebanyak 16 orang $(64,0 \%)$ yang memiliki perilaku kurang baik dan sebanyak 9 orang $(36,0 \%)$ yang memiliki perilaku baik. Sedangkan dari 69 responden berdasarkan dukungan petugas kesehatan sebanyak 18 orang $(26,1 \%)$ yang memiliki perilaku kurang baik dan sebanyak 51 orang $(73,9 \%)$ yang memiliki perilaku baik.baik dan sebanyak 50 orang $(64,9 \%)$ yang memiliki perilaku baik.
Hasil uji statistik nampak ada hubungan antara dukungan petugas kesehatan dengan perilaku WUS tentang deteksi dini kanker leher rahim.

Penelitian ini juga sejalan dengan hasil penelitian Yuliwati (2012) dalam skripsinya tentang faktor-faktor yang berhubungan dengan perilaku WUS dalam deteksi dini kanker leher rahim metode IVA di di wilayah Puskesmas Prembun Kabupaten Kebumen. Hasil uji statistik di peroleh nilai $p$ value 0,000 artinya ada hubungan yang signifikan antara dukungan petugas dengan perilaku WUS dalm melakukan pemeriksaan IVA, yang berarti bahwa yang mendapat dukungan petugas baik berpeluang 2,256 kali lebih besar daripada yang dukungan kurang.

Berdasarkan hal tersebut bahwa petugas kesehatan yang ada di Puskesmas Singgani masih kurang dalam memberikan informasi kepada WUS yang melakukan pemeriksaan dan menjelaskan tentang kanker leher rahim. Sehingga mereka masih belum tahu dan ada juga yang malu dan ragu-ragu apabila ingin melakukan

pemeriksaan.

Sebagian dari petugas kesehatan juga ada yang memberikan informasi kepada ibu-ibu yang melakukan pemeriksaan ketika mereka memberikan saran dalam 
menggunakan alat kontrasepsi. Perlu adanya penyuluhan tentang kanker leher rahim kepada wanita usia subur, sehingga tingkat kesadaran dan kemauan mereka untuk melakukan deteksi dini semakin baik dan berkurangnya angka kejadian kanker leher rahim.

\section{KESIMPULAN}

1. Tidak ada hubungan antara pengetahuan dengan perilaku WUS tentang deteksi dini kanker leher rahim dengan inspeksi visual asam asetat (IVA) di Puskesmas Singgani.

2. Tidak ada hubungan antara pendidikan dengan perilaku WUS tentang deteksi dini kanker leher rahim dengan inspeksi visual asam asetat (IVA) di Puskesmas Singgani.

3. Tidak ada hubungan antara umur dengan perilaku WUS tentang deteksi dini kanker leher rahim dengan inspeksi visual asam asetat (IVA) di Puskesmas Singgani.

4. Tidak ada hubungan antara pekerjaan dengan perilaku WUS tentang deteksi dini kanker leher rahim dengan inspeksi visual asam asetat (IVA) di Puskesmas Singgani.

5. Tidak ada hubungan antara dukungan suami/keluarga dengan perilaku WUS tentang deteksi dini kanker leher rahim dengan inspeksi visual asam asetat (IVA) di Puskesmas Singgani.

6. Ada hubungan antara dukungan petugas kesehatan dengan perilaku WUS tentang deteksi dini kanker leher rahim dengan inspeksi visual asam asetat (IVA) di Puskesmas Singgani.

\section{REKOMENDASI}

1. Bagi Tenaga Kesehatan

Agar melakukan penyuluhan kepada suami tentang deteksi dini kanker leher rahim kepada wanita usia subur untuk pencegahan kanker leher rahim di Puskesmas Singgani. Dan diharapkan suami dapat memberikan dorongan kepada istrinya agar melakukan IVA tes di puskesmas singgani.

2. Bagi Masyarakat

Agar penelitian ini dapat menjadikan sumber informasi dalam deteksi dini kanker leher rahim dengan melakukan pemeriksaan IVA. Dan mengubah tingkat perilaku di masyarakat yang kurang baik menjadi baik.

\section{DAFTAR PUSTAKA}

Dinas Kesehatan Provinsi Sulawesi Tengah, 2014, Profil Kesehatan Provinsi Sulawesi Tengah, Palu, 
Dinas Kesehatan Provinsi Sulawesi Tengah.

Frida, 2015. Faktor-faktor yang Berhubungan dengan Pemeriksaan Inspeksi Visual Asam Asetat pada Wanita Usia Subur di Desa Klumpang Kebun Kecamatan Hamparan Perak Kabupaten Deli Serdang.

Kementerian Kesehatan RI, 2013, Pedoman Teknis Pengendalian Kanker Payudara Dan Kanker Leher Rahim, Jakarta, Kementerian Kesehatan RI.

Ni Luh Putu, 2017.Faktor-faktor yang Berhubungan dengan Pemeriksaan IVA Pada Wanita Pekerja Seksual di Lokaslisasi Sunan Kuning Wilayah Kerja Puskesmas Lebdosari Kota Semarang. Fakultas Keperawatan Universitas Ngudi Waluyo Ungaran.

Puskesmas Singgani Kota Palu, 2015. Profil Puskesmas Singgani, Palu, Puskesmas Singgani Kota Palu.

Samadi, H.P., 2011. Yes, I Know Everything about Kanker serviks, mengenali, mencegahnya \& bagaimana anda menjalani pengobatannya. Metagraf, Creative Imprint of Tiga Serangkai, Solo

Sri Wahyuni, 2013. Faktor-Faktor yang Mempengrauhi Perilaku Deteksi Dini Kanker Serviks di Kecamatan Ngampel Kabupaten Kendal Jawa Tengah. Jurnal Keperawatan Maternitas, Volume 1, Nomor 1, Mei 2013.

Yuliwati, 2012. Faktor-faktor yang Berhubungan dengan Perilaku WUS Dalam Deteksi Dini Kanker Leher Rahim Metode IVA di Wilayah Puskesmas Prembun Kabupaten Kebumen Tahun 2012. Skripsi. Depok, Fakultas Kesehatan Masyarakat Universitas Indonesia

Yuli Kusumawati, dkk, 2016. Pengetahuan, Deteksi Dini dan Vaksinasi HPV Sebagai Faktor Pencegah Kanker Serviks di Kabupaten Sukoharjo. KESMAS 11 (2) (2016) 204-213. Januari 2016. 